\section{NGOs and global trade: non-state voices in EU trade policymaking, by}

Erin Hannah, London, Routledge, 2016, xv +138 pp., $£ 110.00$ (hardback), ISBN 9780415712637

This book examines whether opportunities for non-governmental organisations (NGOs) to participate in the European trade policymaking process have affected the policy positions of the European Union, a key global trading power. As such, it addresses a timely and crucial issue. International trade is ever more contested by citizens and politicians of various stripes, on the grounds of both process and outcome. Trade liberalization processes - and in particular trade negotiations - are criticized as elitist and secretive, and the outcome of the freer trade, it is argued, is often unfair competition, economic dislocation, and a weakening of the economic position of production workers in particular.

The book is divided into five chapters. Chapter 1 introduces the theoretical concepts at the basis of the analysis. The author makes the classical distinction between procedural (input) and substantive (output) legitimacy of policy-making, applying it to NGO participation in EU external trade policy-making processes. Thus, procedural legitimacy can be improved through NGO public education/ awareness activities, NGOs giving voice to otherwise marginalized groups and concerns, and NGO implication in trade policy-making leading to improved public debate, scrutiny, and accountability. Substantive legitimacy is derived from changes in trade policy positions and outcomes, addressing developmental, environmental, and social concerns as a result of NGO participation. The chapter also introduces the central concept of episteme - borrowed from Foucault - as "shared, intersubjective or taken-for-granted causal and evaluative assumptions about how the world works" (p. 24). The author's basic argument throughout the book is that, far more important in influencing EU trade policy positions than formal inclusion or exclusion in policy-making processes is the actors' adoption of the dominant episteme. Thus, only actors within the "legal-liberal" episteme can hope to affect policy-making. By "legal-liberal", the author refers to the hybrid of free trade liberalism and the international legal constraints increasingly imposed on governments through the inclusion of non-political trade dispute mechanisms into the international trade architecture. Chapter 2 constitutes a background to the empirical chapters, by examining how the EU trade policy-making process functions. Its central assertion is that the process has become increasingly open to civil society participation over time, and that in global comparison, the $\mathrm{EU}$ is by far the most open actor in this respect.

Chapters 3 and 4 are devoted to two contrasting cases. In the former - on access to medicines and the evolution of Trade-Related Intellectual Property Rights, TRIPS - NGOs tried to influence outcomes from within the EU policy-making process, making use of the "dramatic and unprecedented efforts" (p. 51) to make external trade policy-making more open to the public. In the latter, on water services liberalization, they worked from outside the corridors of power, using more classical NGO tactics such as grassroots mobilisation, demonstrations and rallies, sensitization through information provision, targeting parliamentarians and journalists, etc. Chapter 5 concludes that in neither of the two cases were progressive NGOs able to affect outcomes (substantive legitimacy). However, procedural legitimacy was increased, as the quality of debates improved, EU policy-makers were forced to refine and justify their arguments, and the public learnt more about the trade/ 
development nexus. The reason for the lack of impact on EU trade policy positions in both cases is, according to the author, that NGOs argue from outside the legal-liberal episteme and are thus in some sense unintelligible to EU trade experts. Moreover, as issues become more technical and complex, policymakers withdraw from public consultation mechanisms.

The author of the book makes her position on free trade clear, namely that "[p]rogressive social values, human health and welfare, and sustainable development hang in the balance" under the dominant episteme that everfurther liberalization will automatically lead to increased welfare for all (p. 124). This clearly stated position notwithstanding, the author produces a balanced account of EU trade policy-making. Sometimes, it is arguably even rather lenient on the EU, generously praising its policy-making openness. Thus, it fails to draw on debates on the tension between input and output legitimacy: What is the value of procedural legitimacy when substantive legitimacy is entirely and continuously absent? How sustainable is such a state of affairs from a democratic standpoint?

The case studies are empirically rich and well conducted. They are also surprisingly readable, given the technical complexity of the trade negotiations that the author relates. However, largely absent from these otherwise well-researched case studies is the substantive content of the arguments made on both sides. How did, for instance, the EU defend its position that water services liberalization and public-private partnerships will lead to better access to water in developing and least developed countries (LDCs)? It is clear that EU policy-makers rely on the legal-liberal episteme, but empirically, what arguments and cases were drawn upon? Idem NGOs? In other words, it is not clear from the book whether the battle in the two cases was fought mainly at a general ideological and normative level or if there was also an ongoing debate about empirical cases past and present and lessons learned from them. Clearly, this research agenda still has a lot to give.

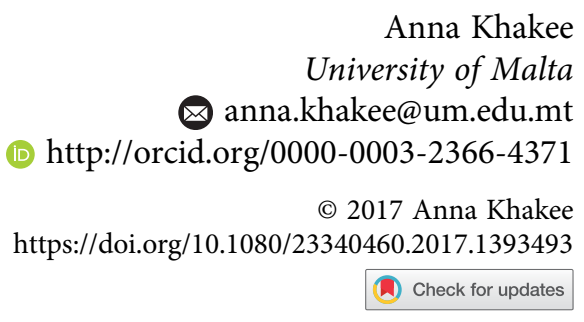

